Agrisaintifika

Jurnal Ilmu-Ilmu Pertanian

Vol. 1, No. 1, 2017

\title{
Kualitas Viskositas dan Kekutan Gel Gelatin Kulit Domba yang Dihidrolisis Mengunakan Larutan $\mathrm{NaOH}$
}

\author{
Yuniarti Dewi Rahmawati ${ }^{1}$ dan Muhamad Hasdar ${ }^{2}$ \\ ${ }^{1)}$ Program Studi IImu Gizi, Universitas Muhadi Setiabudi, Brebes \\ ${ }^{2)}$ Program Studi IImu dan Teknologi Pangan, Universitas Muhadi Setiabudi, Brebes \\ email : yuniartidewirahmawati@ymail.co.
}

\begin{abstract}
Abstrak
Penelitian ini bertujuan untuk mengetahui kualitas viskoitas dan kekuatan gel gelatin kulit domba yang hidrolisis menggunakan larutan $\mathrm{NaOH}$. Penelitian ini mengunakan kosentasi larutan $\mathrm{NaOH}(1 \%, 2 \%, 3 \%, 4 \%$ dan $5 \%$ b/v) dengan lama perendaman 3 jam. Desain penelitian mengunakan rancangan acak lengkap pola searah. Kualitas viskositas terbaik dengan nilai 2,35 $\pm 0,03 \mathrm{cP}$ dan kualitas kekuatan gel terbaik dengan nilai 123,26 $\pm 0,63$ bloom. Kualitas viskositas dan kekuatan gel pada penelitian ini masih memenuhi syarat GMIA.
\end{abstract}

Kata kunci : gelatin, kekuatan gel, kulit domba, $\mathrm{NaOH}$, viskositas

\section{PENDAHULUAN}

Gelatin merupakan biopolimer yang memiliki aplikasi yang sangat luas di industri pangan, farmasi, maupun di industri fotografi. Gelatin memiliki kekhasan dibandingkan dengan agen gelling yang lain yaitu memiliki viskositas dan kekuatan gel yang sangat baik untuk berbagai produk pangan maupun produk non pangan. Viskositas atau kekentalan gelatin sering dimanfaatkan di bidang pengolahan pangan elmulsifier, stabilizer atau sebagai penjernih air pada sirup. Pengembangan aplikasi gelatin juga dilakukan sebagai pengemas bahan pangan misalnya edible coating atau edible film yang dikombinasikan dengan protein nabati (Hasdar et al., 2011). Pada bidang fotografi gelatin digunakan untuk memperpanjang daya simpan foto, karena gelatin dapat berfungsi sebagai pelindung cahaya yang sensitif. Gelatin yang memiliki keluatan gel yang tinggi akan mampu melindungi penyimpanan foto dari cahaya sensitif yang akan merusak daya simpan foto. Kualitas viskositas atau kekentalan gelatin dipengaruhi dua faktor seperti perlakuan saat pengolahan gelatin dan bahan baku gelatin.
Kedua faktor ini mampu mempengaruhi panjang pendeknya rantai peptida kolagen gelatin. Faktor perlakuan saat pengolahan gelatin sangat menetukan kualitas fisik seperti perlakuan penggunaan larutan asam dan larutan basa, perlakuan lama perendaman, perlakuan metode ekstraksi.

Pemilihan bahan baku gelatin selalu menjadi isu penting dalam penelitian pengembangan sumber bahan baku gelatin. Indonesia sampai saat ini bukanlah produsen gelatin, sebagian besar gelatin yang beradar di indonesia merupakan impor dari negara lain. Gelatin impor yang beredar diindonesia masih diragukan kehalalannya Gelatin yang berbahan baku babi sangat tidak diterima di Indonesia yang masyarakatnya mayoritas muslim, sehingga beberapa penelitian mengangkat isu sumberdaya lokal untuk memproduksi gelatin seperti penelitian Agustin dan Sompie (2015) yang mengangkat potensi lokal kulit ikan tuna, Penelitian Said (2011) yang mengangkat potensi gelatin dari kulit kambing, Penelitian Ulfah (2011) tentang potensi ceker ayam sebagai gelatin, dan penelitian Masrukan (2015) yang mengkaji gelatin kulit kerbau. Gelatin yang dihidrolisis dari bahan baku lokal 
Agrisaintifika

Jurnal Ilmu-Ilmu Pertanian

Vol. 1, No. 1, 2017

Rahmawati \& Hasdar, 2017

akan menjadi sumber gelatin yang potensial untuk dikembangkan. Seperti pada penelitian ini mengangkat tema potensi gelatin domba yang bertujuan untuk mengetahui kualitas viskositas dan kekuatan gel gelatin kulit domba yang hidrolisis menggunakan larutan $\mathrm{NaOH}$. Pada penelitian ini juga mengkaji kemampuan $\mathrm{NaOH}$ sebagai basa kuat harus lebih dieksplorasi dalam proses hidrolisis protein kolagen yang terdapat dalam kulit domba.

\section{METODE}

\section{Materi}

Bahan utama yang digunakan dalam penelitian ini yaitu kulit domba yag berasal dari Kabupaten Brebes yang berumur 1 - 2 tahun. Bahan perendam yang digunakan yaitu $\mathrm{NaOH}$ dengan konsentrasi $1 \%, 2 \%, 3 \%, 4 \%$ dan $5 \%$ $(\mathrm{b} / \mathrm{v})$. Bahan lain yang digunakan yaitu aquades dan air. Peralatan yang digunakan dalam pembuatan gelatin adalah timbangan analitik, saringan, hot plate, termometer, gelas ukur, gelas beaker, cawan petri, labu ukur, erlemeyer.

\section{Metode}

Penelitian ini meliputi proses pembuatan gelatin dan analisa kualitas fisik yaitu kualitas viskositas dan kualitas kekuatan gel gelatin. Viskositas diukur dengan cara bubuk gelatin dilarutkan dalam aquades pada suhu $40^{\circ} \mathrm{C}$ dengan konsentrasi larutan $6,67 \%$. Nilai viskositas diukur dengan Stromer Viscosimeter Behlin CSR-10, nilai yang diperoleh dinyatakan dalam centipoise sesuai metode Gomez-Guillen et al., (2002). Kekuatan gel diukur dengan menyiapkan larutan gelatin konsentrasi $6,67 \% \quad(b / v)$. Larutan diaduk dengan menggunakan magnetic stirrer sampai homogen, kemudian dipanaskan sampai suhu $60^{\circ} \mathrm{C}$ selama 15 menit. Larutan dituang dalam standard bloom jars (botol dengan diameter $58-60 \mathrm{~mm}$, tinggi $85 \mathrm{~mm}$ ), ditutup dan didiamkan selama 2 menit. Dilanjutkan dengan inkubasi pada suhu $10^{\circ} \mathrm{C}$ selama $17 \pm 2$ jam dan kekuatan gel diukur

menggunakan alat TA-XT Plus Texture Analyzer pada kecepatan probe $0,05 \mathrm{~mm} / \mathrm{s}$ dengan kedalaman $4 \mathrm{~mm}$. Kekuatan gel dinyatakan dalam satuan g Bloom.

\section{Proses Pembuatan Gelatin}

Kulit domba segar yang didapatkan dari rumah pemotongan hewan di Kabupaten Brebes terlebih dahulu dipisahkan antara kulit dan wool dengan menggunakan silet kerok yang tajam. Kemudian dilakukan pengbuangan sisa-sisa daging atau lemak yang masih menempel pada kulit dengan menggunkan pisau tajam. Lalu selanjutnya dicuci dengan air bersih. Kulit yang telah bersih dari wool dan sisa-sisa daging/lemak ditiriskan agar air tidak banyak tertinggal dikulit. Kemudian di lakukan penimbangan kulit segar lalu di kulit segar di kecilkan ukuranya menjadi $\pm 2 \times 2 \mathrm{~cm}$. Selanjutnya direndam pada larutan $\mathrm{NaOH} 1 \%$, $2 \%, 3 \%, 4 \%$ dan $5 \%(\mathrm{~b} / \mathrm{v})$ dengan lama waktu perendaman yang berbeda yaitu selama 3 jam. Hasil Perendaman kulit domba kemudian di ekstrak dengan menggunakan metode hot treatment dengan temperatur $50-55^{\circ} \mathrm{C}$ yang dilakukan secara bertingkat selama 4 jam, 3 jam, dan 2 jam. Selanjutnya dilakukan proses pengeringan untuk memperoleh gelatin kering berbentuk lembaran. Proses pembuatan ini mengikuti proses pembuatan gelatin pada penelitian sebelumnya (Hasdar dan Rahmawati, 2017).

\section{Analisis Statistik}

Penelitian ini menggunakan Rancangan Acak Lengkap (RAL) pola searah, bahan perendam yang digunakan yaitu $\mathrm{NaOH}(\mathrm{g} / \mathrm{l})$, sebagai faktor utama yaitu dengan kosentrasi bahan perendam $1 \%, 2 \%, 3 \%, 4 \%$ dan $5 \%$ (b/v). Masing-masing perlakuan diulang sebanyak tiga (3) kali. Analisis penelitian ini menggunakan metode analisis ragam. Semua data yang diperoleh, kemudian dianalisis dengan metode One-Way ANOVA pola searah menggunakan SPSS 17.0 Statistic Software. Level signifikan yang ditetapkan sebesar $\alpha=$ 0,05 . 
Agrisaintifika

Jurnal Ilmu-Ilmu Pertanian

Vol. 1, No. 1, 2017

Rahmawati \& Hasdar, 2017

\section{HASIL DAN PEMBAHASAN}

Berdasarkan hasil pengamatan dari kualitas fisik gelatin kulit domba yang di rendam dengan $\mathrm{NaOH} 1 \%, 2 \%, 3 \%, 4 \%$ dan $5 \%$ (b/v) selama 3 jam. Pada Penelitian ini mengkaji sifat fisik gelatin yang berupa viskositas dan kekuatan gel.

\section{Pengaruh Perlakuan Terhadap Viskositas Gelatin}

Viskositas atau kekentalan gelatin merupakan salah satu sifat fisik gelatin yang cukup penting. Pengujian viskositas dilakukan untuk mengetahui tingkat kekentalan gelatin sebagai larutan pada konsentrasi tertentu.

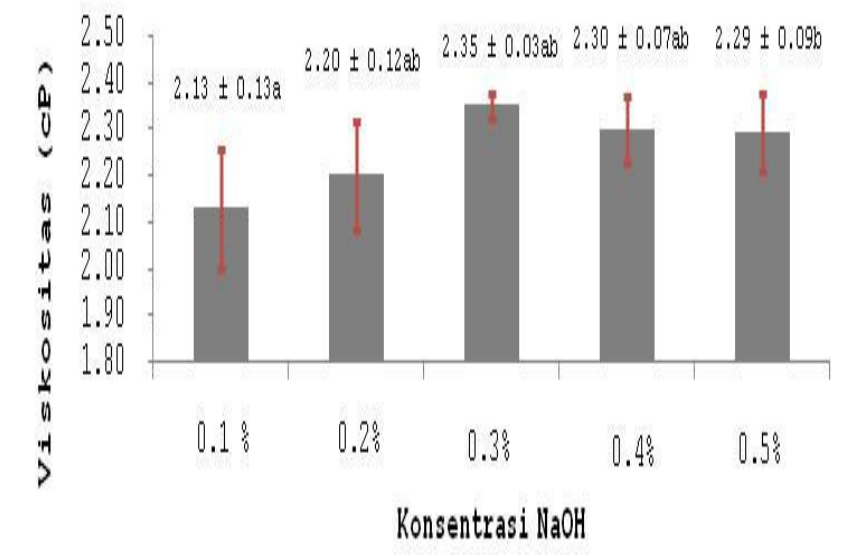

Gambar 1. Grafik Pengaruh Konsentrasi Terhadap Nilai Viskositas Gelatin Kulit Domba

\footnotetext{
Berdasarkan Gambar 1 dapat diketahui bahwa kemampuan $\mathrm{NaOH}$ dalam menghidrolisis ikatan triple heliks molekul peptida kolagen mengahasilkan viskositas antara 1,99 - 2,39 cP. Nilai ini sesuai dengan standar yang ditetapkan oleh GMIA (2017) yaitu antara 1,5 - 7,5 cP. Pada penelitian ini viskositas terbaik terdapat pada gelatin kulit domba yang direndam menggunakan $\mathrm{NaOH}$ $0,3 \%$ sebesar $2.35 \pm 0.03 \mathrm{cP}$. Kemampuan larutan $\mathrm{NaOH}$ dalam menghidrolisis peptida kolagen kulit domba belum begitu baik, sehingga berat molekul gelatin juga tidak begitu tinggi yang mengakibatkan viskositas
}

gelatin kulit domba belum bisa mencapai titik standar tertinggi dari standar GMIA. Tingginya rendahnya nilai viskositas sangat dipengaruhi oleh distribusi molekul peptida gelatin dalam larutan serta berat molekul dari peptida gelatin (Nishimoto et al., 2005). Semakin besar berat molekul dari gelatin maka distribusi molekul gelatin dalam larutan semakin lambat sehingga menghasilkan nilai viskositas yang tinggi (Mariod dan Adam, 2013).

Berdasarkan gambar 1. terlihat bahwa faktor konsentrasi $\mathrm{NaOH}$ sangat berpengaruh dalam menghasilkan nilai viskositas $(P<0,05)$. Hal ini juga didukung oleh hasil uji Duncan yang mengambarkan konsentrasi $\mathrm{NaOH} 0,1 \%$ dan $\mathrm{NaOH} 0,5 \%$ tidak menunjukan perbedaan nilai viskositas, namun konsentrasi $\mathrm{NaOH} 0,3 \%$ menunjukan perbedaan nilai viskositas pada semua perlakuan. Perlakuan yang berbeda akan menghasilkan nilai viskositas dan kandungan air berbeda dalam gelatin. Kadar air yang tinggi pada gelatin dapat menurunkan nilai viskositas (Olivares et al., 2006), proses pengeringan yang berlebihan akan dapat memutus ikatan protein gelatin sehingga mengakibatkan kualitas viskositas juga rendah dan kandungan air yang tinggi akan mengakibatkan gel dari gelatin menjadi sulit mengental.

\section{Pengaruh Perlakuan Terhadap Kekuatan Gel Gelatin}

Kekuatan gel sangat penting dalam penentuan perlakuan terbaik dalam proses ekstraksi gelatin karena salah satu sifat penting gelatin adalah mampu mengubah cairan menjadi padatan atau mengubah sol menjadi gel yang reversible (Trilaksani et al., 2012). Hasil pengukuran kekuatan gel gelatin kulit domba dengan perlakuan konsentrasi $\mathrm{NaOH}$ yang berbeda dapat dilihat pada gambar 2 . 
Agrisaintifika

Jurnal Ilmu-Ilmu Pertanian

Vol. 1, No. 1, 2017

Rahmawati \& Hasdar, 2017

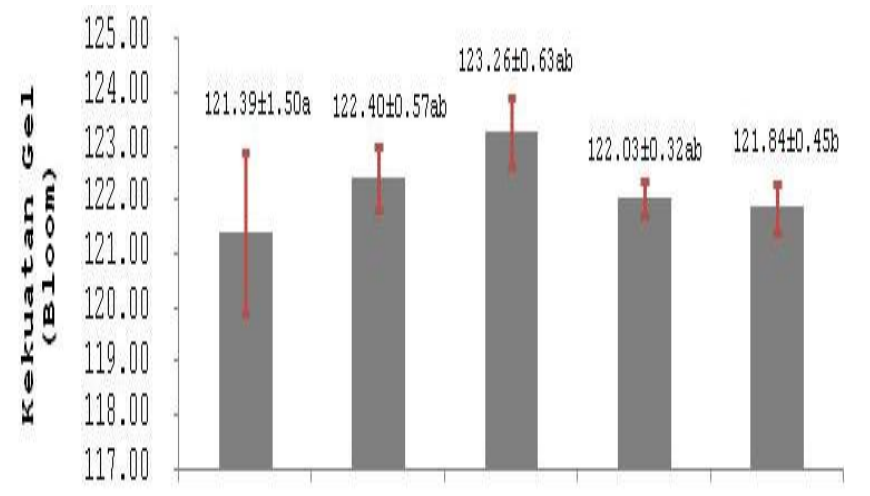

$0.18 \quad 0.28 \quad \begin{gathered}0.38 \\ \text { Ronsentrasi NaOH }\end{gathered}$

Gambar 2. Grafik Pengaruh Konsentrasi Terhadap Kekuatan Gel Gelatin Kulit Domba

Berdasarkan gambar 2. terlihat konsentrasi $\mathrm{NaOH} \quad 0.3 \%$ berbeda nyata $(P>0,05)$ dengan konsentrasi lainnya dalam menghasilkan kekuatan gel gelatin kulit domba. Konsentrasi $\mathrm{NaOH} \quad 0,1 \%$ dan $0,5 \%$ menunjukan kesamaan dalam mengahasilkan kekuatan gel gelatin kulit domba. Kekuatan gel pada penelitian ini berada pada kisaran 119.85-123.71 bloom. Kekuatan gel ini masih memenuhi syarat GMIA (2017) yaitu $50-300$ bloom. Nilai kekuatan gel dibawah 50 bloom akan membuat gelatin sulit untuk membentuk gel sedangkan nilai kekuatan gel lebih dari 300 bloom akan membuat gelatin lebih kaku dan

\section{DAFTAR PUSTAKA}

Agustin, A. T., dan Sompie, M. 2015. Kajian Gelatin Kulit Ikan Tuna (Thunnus Albacares) Yang Diproses Menggunakan Asam Asetat. Proseding Seminar Nasional Masyarakat Biodiversitas Indonesia. Vol. 1 (5) ; 1186 - 1189.

GMIA. 2017. Gelatin Manufacturer Institute of America 2017, The Gelatin Handbook. http://www.gelatin- keras. Kekuatan gel terbaik yaitu 123,26 \pm 0.63 bloom. Perbedaan kekuatan gel ini disebabkan oleh proses hidrolisis kolagen akibat perbedaan konsentrasi $\mathrm{NaOH}$. Perbedaan metode hidrolisis dengan $\mathrm{NaOH}$ mengakibatkan perbedaan ukuran rantai peptida kolagen. Konsentrasi $\mathrm{NaOH} \quad 0,3 \%$ mampu mengkonversi kolagen menjadi gelatin secara efektif. Artinya ukuran rantai peptida kolagen gelatin yang dihidrolisis dengan $\mathrm{NaOH}$ $0,3 \%$ lebih panjang dibandingkan dengan perlakuan yang lain. Ukuran panjang rantai peptida gelatin berkaitan dengan berat molekul produk gelatin tersebut. Semakin panjang rantai pepetidanya, maka semakin besar pula berat molekulnya dan semakin tinggi pula nilai kekuatan gelnya (Hardikawati et al., 2016).

\section{KESIMPULAN}

Berdasarkan hasil penelitian yang telah dilakukan dapat disimpulkan bahwa penggunaan $\mathrm{NaOH}$ dengan konsentrasi $0,3 \%$ sebagai bahan perendam lebih efektif dibadingkan dengan konsetnrasi yang lain. Kualitas viskositas terbaik dengan nilai 2,35 \pm $0,03 \mathrm{cP}$ dan kualitas kekuatan gel terbaik dengan nilai 123,26 $\pm 0,63$ bloom. Kualitas viskositas dan kekuatan gel pada penelitian ini masih memenuhi syarat GMIA.

gmia.com/gelatinhandbook.html. [Diakses 20-05-2017].

Gomes-Guillen, M.C., J. Turney, M.D. Fernandez Diaz, N. Ulmo, M.A. Lizarbe and P. Montero. 2002. Structural and Physical Properties of Gelatin Extracted From Different Marine species : Comparative Study. Food Hydrocolloids, Vol. 16 (1) : 25 - 34. 
Hardikawati, H., Puspawati N. M.,, dan Ratnayani, K., 2016. Kajian Pengaruh Variasi Konsentrasi Asam Sitrat Terhadap Kekuatan Gel Produk Gelatin Kulit Ayam Broiler Dikaitkan Dengan Pola Proteinnya. Jurnal Kimia 10 (1) ; 115 - 124.

Hasdar, M. dan Rahmawati,D.M.,2017. Kajian Potensi Kulit Domba Asal Brebes Sebagai Bahan Dasar Produksi Gelatin Halal. Jurnal Aplikasi Teknologi Pangan. Vol 6 (1) : 1 - 6 .

Hasdar, M., Triatmojo, S., dan Erwanto, Y. 2011. Karakteristik Edible Film Yang Diproduksi Dari Kombinasi Gelatin Kulit Kaki Ayam Dan Soy Protein Isolate. Buletin Peternakan. Vol. 35(3): 188 - 196.

Mariod A. A., dan Adam H.F., 2013. Review: Gelatin, Source, Extraction And Industrial Applications. Acta Sci. Pol., Technol. Aliment. Vol.12 (2) : 135 - 147.

Masrukan, 2015. Karakteristik Gelatin Kulit Kerbau Dan Aplikasinya Sebagai Enkapsulan Minyak Atsiri Daun Cengkeh (Syzygium aromaticum). [Tesis]. Fakultas Teknologi Pertanian, Universitas Gadjah Mada, Yogyakarta.
Nishimoto M., Sakamoto R., Mizuta S., Yoshinaka R., 2005. Identification and Characterization of Molecular Species of Collagen in Ordinary Muscle and Skin of the Japanese flounder (Paralichthys olivaceus). Journal Food Chemistry. Vol 90(1-2) : 151 - 156.

Olivares M.L., Peirotti M.B., Deiber J.A. 2006. Analysis of Gelatin Chain Aggregation in dilute Aqueous Solutions Through Viscosity Data. Food Hydrocolloids. Vol 20 (7), 1039-1049.

Said M.I., Triatmojo S, Erwanto Y, dan Fudholi A. 2011. Karakteristik Gelatin Kulit Kambing Yang Diproduksi Melalui Proses Asam Basa. Jurnal Agritech. Vol. 31 (3): 0216 - 0455.

Trilaksani, W., Nurilmala, M., dan Setiawati, I.H., 2012. Ekstraksi Gelatin Kulit Ikan Kakap Merah (Lutjanus sp.) Dengan Proses Perlakuan Asam. Jurnal Pengolahan Hasil Perikanan Indonesia. Vol. 15 (3) : 240 - 251.

Ulfah M. 2011. Pengaruh Konsentrasi Larutan Asam Asetat Dan Lama Waktu Perendaman Terhadap Sifat-Sifat Gelatin Ceker Ayam. Jurnal Agritech 31 (3): 161 167. 